\title{
A web-based survey for COVID-19 infection among Indian dancers
}

Pratiti Ghosh ${ }^{1}$

${ }^{1}$ Freelance researcher

January 22, 2021

\section{Abstract}

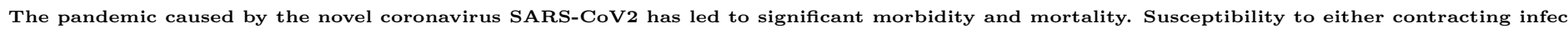
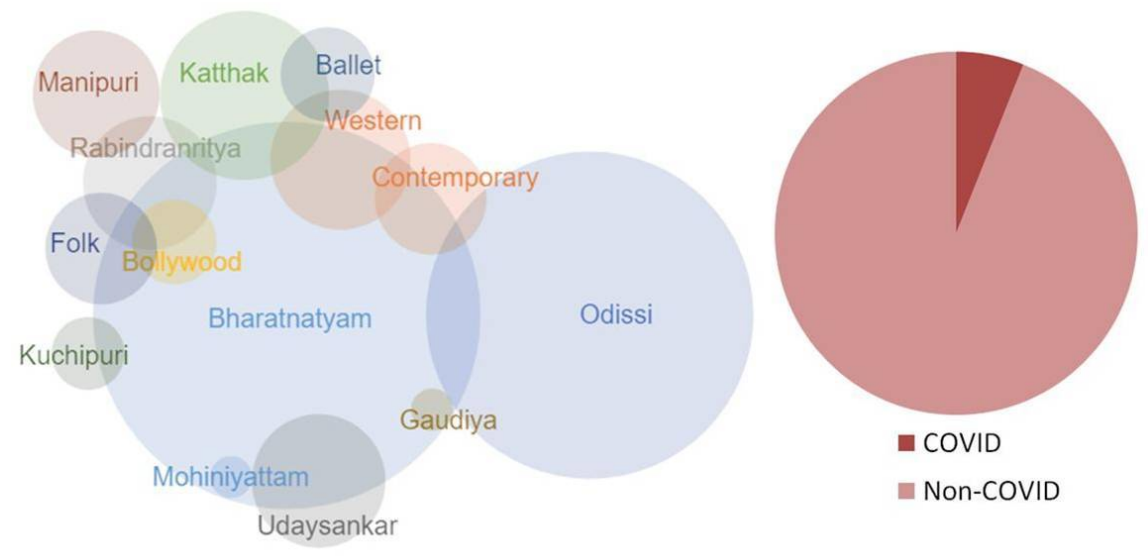

Figure 1: This is a caption

\section{Hosted file}

Manuscript with figures GhoshP.pdf available at https://authorea.com/users/391133/articles/ 505314-a-web-based-survey-for-covid-19-infection-among-indian-dancers 